\title{
New Distributional Records for the Himalayan White-lipped Pitviper, Trimeresurus septentrionalis Kramer 1977 (Reptilia: Viperidae) from the Garhwal Himalaya in Northwestern India
}

\author{
Abhishek Singh ${ }^{1}$, Kanchan Puri ${ }^{2}$, and Ritesh Joshi ${ }^{2,3}$
}

\begin{abstract}
${ }^{1}$ Endangered Flora and Fauna on Earth Conservation Team, Vasant Vihar, Dehradun, Uttarakhand, India (effect.abhishek@gmail.com) ${ }^{2}$ Environment Education Division, Ministry of Environment, Forest \& Climate Change, New Delhi, India (genetics_1407@yahoo.co.in) ${ }^{3}$ Conservation \& Survey Division, Ministry of Environment, Forest \& Climate Change, New Delhi, India (ritesh_joshi2325@yahoo.com)
\end{abstract}

$\mathrm{T}_{\mathrm{t}}^{\mathrm{h}}$ he Himalayan White-lipped Pitviper (Trimeresurus septentrionalis), also known as the Northern White-lipped Pitviper and sometimes assigned to the genus Cryptelytrops (e.g., Malhotra and Thorpe 2004; Malhotra et al. 2011), has previously been recorded from Nepal (Giannasi et al. 2001; Leviton et al. 2003; Sharma et al. 2013), Bangladesh (Uetz et al. 2017), and northwestern India, where it is known from only a few localities in Uttarakhand State (Theophilus et al. 2008), although Leviton et al. (2003) reported the presence of "Trimeresurus albolabris septentrionalis" in Shimla, Himachal Pradesh. Chandna (2007) and Theophilus et al. (2008) listed the elevational range in India as $-1,000-1,150 \mathrm{~m}$, and Sharma et al. (2013) listed it as 900-3,050 m in Nepal.

Chandna (2007), in his notes on a case of snakebite in the Mori area in the Uttarkashi District of Uttarakhand State, stated that he found two snakes, which had been killed by locals, that probably were Himalayan White-lipped Pitvipers. Romulus Whitaker visited the site with him and supported the contention that the species was likely there. Theophilus et al. (2008) indicated that the Himalayan White-lipped Pitviper also had been found in the Gori River Valley in Dharchula Tehsil of the Pithoragarh District at an elevation of nearly 1,000 m. However, Whitaker and Captain (2004) and Vasudevan and Sondhi (2010) included the Himalayan White-lipped Pitviper only in the checklists of snakes in India and Uttarakhand, respectively, without providing descriptions or locality records.

During the last few years, reports of human fatalities due to snakebites sustained in forested areas were received from the Pithoragarh District in Uttarakhand State. However, few of the deaths in the area were attributed to green-colored snakes, locally called "green pitvipers" (Bhupesh Pant,

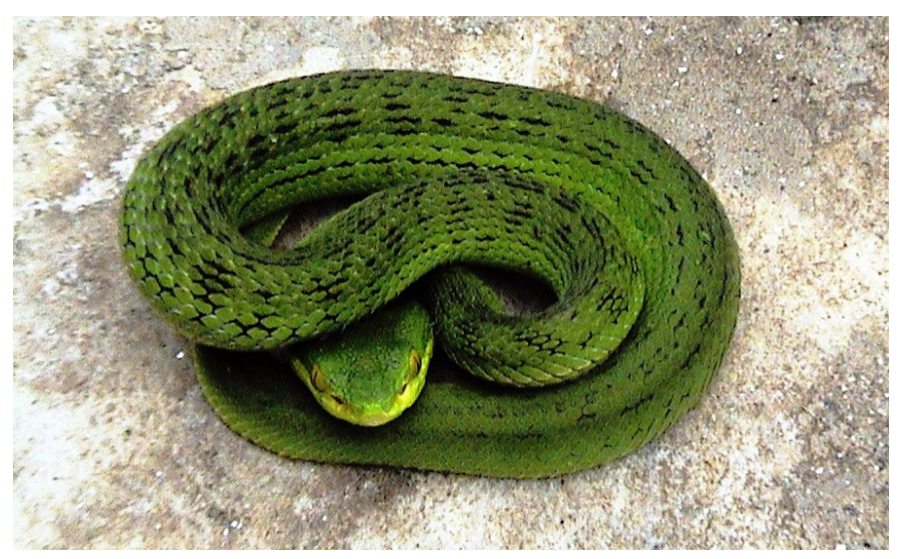

Fig. 1. Himalayan White-lipped Pitviper photographed from Munsyari area of Pithoragarh district, Uttarakhand. Photograph by Ritesh Joshi.

pers. comm.). Photographic evidence (Fig. 1) suggests that the Himalayan White-lipped Pitviper occurs in that area. Theophilus et al. (2008) pointed out that most snakebites in the Bungapani area in the subtropical belt along the Gori River were caused by Himalayan White-lipped Pitvipers, so far apparently without cases of fatal envenomation.

At $0310 \mathrm{~h}$ on 28 September 2015, we found a Himalayan White-lipped Pitviper (sex unknown; Fig. 2) along the Dehradun-Sahastra Dhara road in the Mussoorie Forest Range of the protected forest of the Mussoorie Forest Division near Dehradun $\left(30^{\circ} 23^{\prime} 06.4 " \mathrm{~N}, 78^{\circ} 07^{\prime} 27.9^{\prime \prime} \mathrm{E}\right.$, $832.3 \mathrm{~m}$ ). At $1340 \mathrm{~h}$ on 24 July 2016, we found another Himalayan White-lipped Pitviper of unknown sex (Fig. 3) on the Dehradun-Maldevta-Dhaunalti road $\left(30^{\circ} 21^{\prime} 39.3^{\prime \prime N}\right.$, $78^{\circ} 08^{\prime} 24.2^{\prime \prime E}, 784.5 \mathrm{~m}$ ) nearly 20 kilometers from the location where the first snake was encountered. This site also lies in the Mussoorie Forest Range of the Mussoorie 


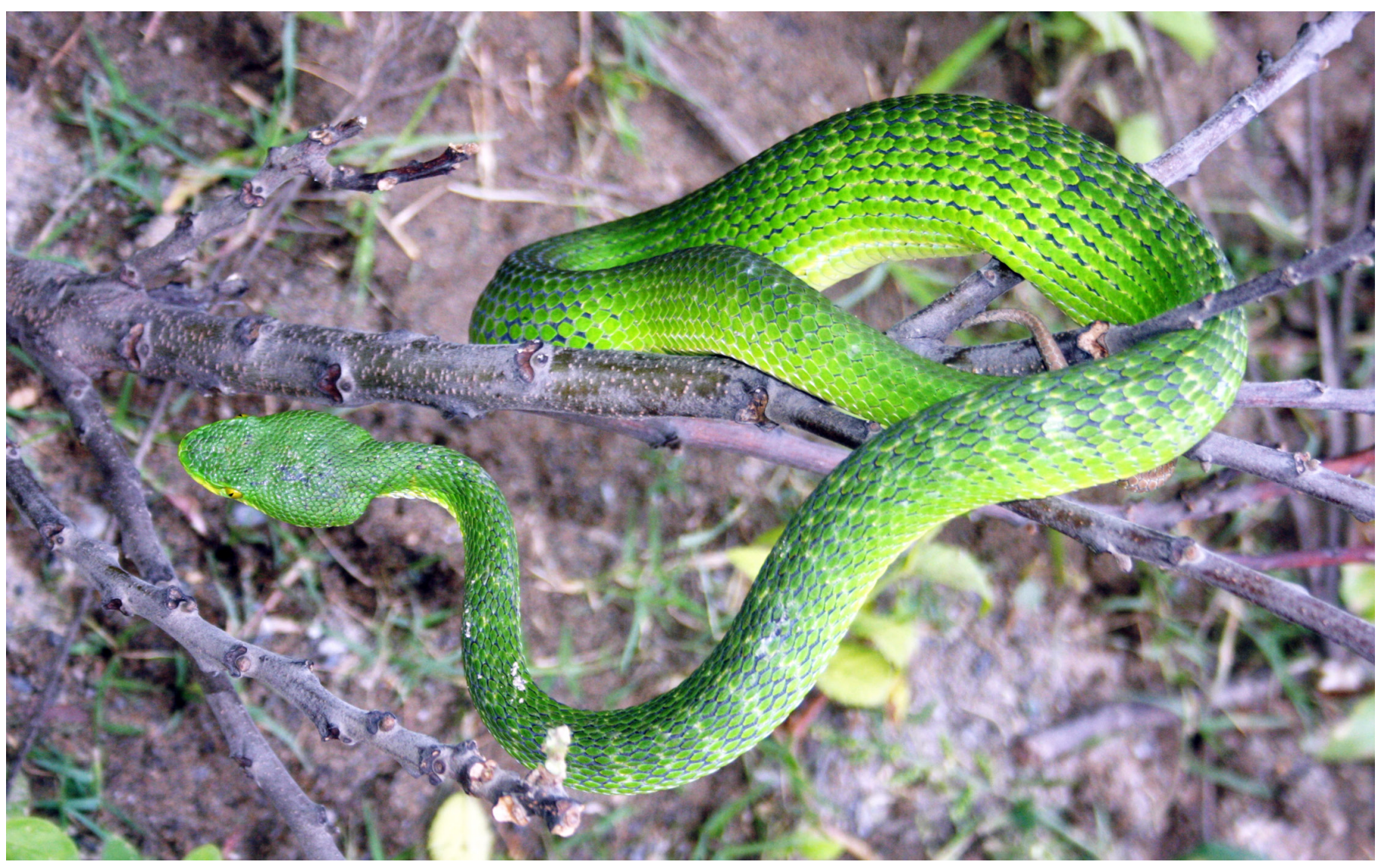

Fig. 2. Himalayan White-lipped Pitviper (Trimeresurus septentrionalis) at an elevation of $832.3 \mathrm{~m}$ in the Mussoorie Forest Division, near Dehradun, Uttarakhand, India. Photograph by Abhishek Singh.

Forest Division, and both localities are in the Himalaya Biogeographic Zone and the West Himalaya Province (Rodgers et al. 2002). The largest portion of this area is in Shivalik's Biogeographic Subdivision, which constitutes an important repository of reptilian fauna. Plant species in the areas where the snakes were seen included Flemingia chappar (Charchara), Albizia spp. (siris), Bombax ceiba (Semal), Murraya koenigii (Curry Tree), Lantana camara (Lantana), Carissa carandas (Karonda), Colebrookea oppositifolia (Indian Squirrel Tail), Datura stramonium (Jimson Weed), and Parthenium hysterophorus (Congress Grass). Both sightings occurred during the monsoon season. We photographed the snakes and identified them based on descriptions in Sharma et al. (2013) and Uetz et al. (2017). The identities were confirmed from photographs by Romulus Whitaker, Ashok Captain, and Anita Malhotra.

The Himalayan White-lipped Pitviper has sometimes been confused with the White-lipped Pitviper (Trimeresurus albolabris). In India, Whitaker and Captain (2004) reported the range of the latter as northeastern India (Assam and West Bengal States), but others (Sharma 2007; Saikia et al. 2007; Sharma and Sidhu 2016; Negi and Banyal 2016) have also recorded this species from Himachal Pradesh State. Information on the serpents of Uttarakhand State is sparse and scattered. Even authenticated information on the geographic distribution of many threatened species is lacking, mainly due to a paucity of herpetological surveys. Consequently, reliable data are rare because of the difficulty in sampling these patchily distributed, cryptic, and largely nocturnal species. Considerable work remains before the distribution and status of the pitvipers of the Himalayan Region and northeastern India in general is understood. In addition, Anita Malhotra (pers. comm.) suggested that some new species remain unidentified. Nevertheless, these new records confirm the occurrence of T. septentrionalis in the Garhwal Himalaya, and provide the lowest known elevational record for the species.

The Himalayan White-lipped Pitviper has not been assessed for the IUCN Red List. Increasing development and anthropogenic activities along perennial streams, shrinkage of natural water sources inside protected areas, expansion of the road network through the chain of protected habitats, and a lack of awareness among the local people are some of the threats that likely will lead to declines in the numbers and populations of this species.

\section{Acknowledgements}

We thank Romulus Whitaker, Ashok Captain, and Anita Malhotra for confirming the identities of the snakes. We 

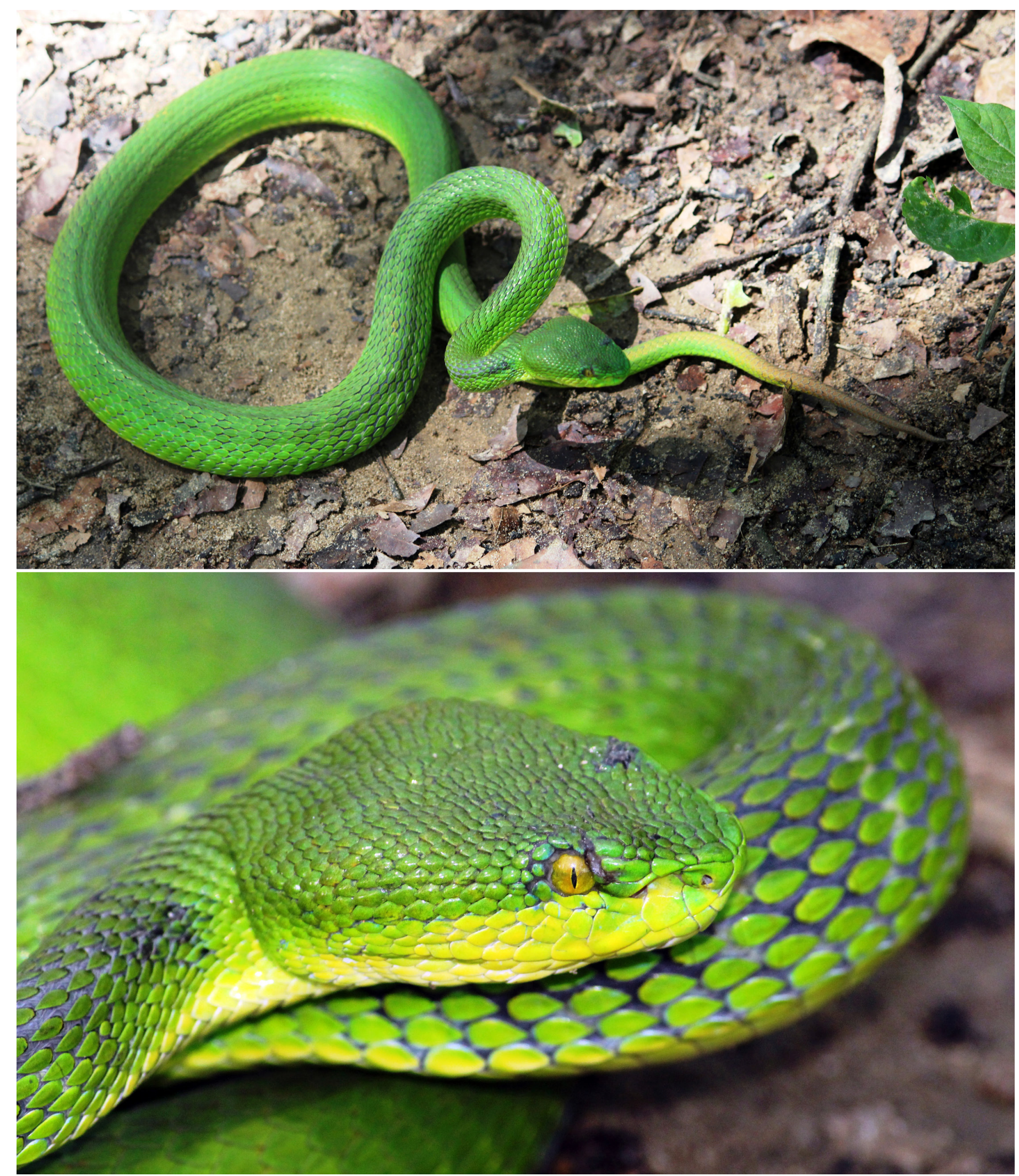

Fig. 3. Himalayan White-lipped Pitviper in its natural habitat at an elevation of $784.5 \mathrm{~m}$ in the Mussoorie Forest near Dehradun, Uttarakhand, India. Photograph by Abhishek Singh.

also thank Sudhakar Sharma and Raj Shekhar Singh for their assistance in the field and V.D. Sahni for helpful comments on an earlier draft of this manuscript.

\section{Literature Cited}

Chandna, T. 2007. A case of snake bite-possibly by the Himalayan white-lipped pitviper Cryptelytrops septentrionalis. <http://madrascrocbank.blogspot. 
in/2007/07/case-of-snake-bitepossibly-by-himalayan.html>.

Giannasi, N., R.S. Thorpe and A. Malhotra. 2001. The use of amplified fragment length polymorphism in determining species trees at fine taxonomic levels: Analysis of a medically important snake, Trimeresurus albolabris. Molecular Ecology 10: 419-426.

Leviton, A.E., G.O.U. Wogan, M.S. Koo, G.R. Zug, R.S. Lucas and J.V. Vindum. 2003. The dangerously venomous snakes of Myanmar, illustrated checklist with keys. Proceedings of the California Academy of Sciences 54: 407-462.

Malhotra, A. and R.S. Thorpe. 2004. A phylogeny of four mitochondrial gene regions suggests a revised taxonomy for Asian Pitvipers (Trimeresurus and Ovophis). Molecular Phylogenetics and Evolution 32: 83-100.

Malhotra, A., R.S. Thorpe, Mrinalini, and B.L. Stuart. 2011. Two new species of pitviper of the genus Cryptelytrops Cope 1860 (Squamata: Viperidae: Crotalinae) from Southeast Asia. Zootaxa 2757: 1-23.

Negi, R.K. and H.S. Banyal. 2016. A preliminary study on the species composition of vertebrates in Rakchham-Chhitkul Wildlife Sanctuary in Trans-Himalayan Baspa (Sangla) Valley, District Kinnaur, Himachal Pradesh, India. IOSR Journal of Pharmacy and Biological Sciences 11: 51-60.

Rodgers, W.A., H.S. Panwar, and V.B. Mathur. 2002. Wildlife Protected Areas in India: A Review (Executive Summary). Wildlife Institute of India, Dehradun, India.
Saikia, U., D.K. Sharma, and R.M. Sharma. 2007. Checklist of the reptilian fauna of Himachal Pradesh, India. Reptile Rap 8: 6-9.

Sharma, R.C. 2007. The fauna of India and the adjacent countries-Reptilia, p. 410. In: Zoological Survey of India. Kolkata, India.

Sharma, I. and A.K. Sidhu. 2016. Faunal diversity of all vertebrates (excluding Aves) of Himachal Pradesh. Biological Forum 8: 1-26.

Sharma, S.K., D.P. Pandey, K.B. Shah, F. Tillack, F. Chappuis, C.L. Thapa, E. Alirol and U. Kuch. 2013. Venomous Snakes of Nepal. A Photographic Guide. B.P. Koirala Institute of Health Sciences, Dharan, Nepal.

Theophilus, E., A. Captain, F. Tillack, and U. Kuch. 2008. Reptilia, Elapidae, Bungarus niger: Distribution extension and first record for the State of Uttarakhand, India, with notes on snakebites in the Gori River Valley. Check List 4: 404-409.

Uetz, P., P. Freed, and J. Hošek (eds.). 2017. The Reptile Database. <http://www. reptile-database.org>.

Vasudevan, K. and S. Sondhi. 2010. Amphibians and reptiles of Uttarakhand, India. Wildlife Institute of India, Dehradun, Uttarakhand, India.

Whitaker, R. and A. Captain. 2004. Snakes of India. The Field Guide. Draco Books, Chennai, India. 